\title{
The Role of NGOs (Non-governmental organizations) in Participatory Prevention of Environmental crimes
}

\author{
Shirin Aghajani '
}

\begin{abstract}
Crimes against the environment are actions that in certain circumstances cause Pollution, destruction or damage to the environment. The importance of preventing these crimes is because it relates directly to the health of human beings. Today non-governmental actors play an important role in the national and international arena. The Geographical diversity of activities and their different functions has led to state actors cannot be indifferent to the role of these new actors. NGOs are involved in two "competing" or "partner" forms of governments. In issues related to human rights, these to be a competitor to governments. While in the case of issues such as health development and environment it is considered as a partner of governments. In Iran's legal system the action role of these organizations in regard to environmental protection is undeniable: But there is still a lot of vacuum at the reactionary stage: must provide suitable substrates for the active Participation of this actors in environmental litigation: In a way that they can achieve a favorable position in criminal proceedings: Also, the organization of NGOS as the right hand of governments in helping to solve these problems has also a special place. The research method was descriptive-analytic and the date was collected as a library. In this research we decided to investigate the role of grassroots institutions in preventing environmental crime and accomplish the strengths and weaknesses of these institutions.
\end{abstract}

Keywords: Environmental crimes; Prevention; NGOs; Environmental; Laws 


\section{Introduction}

The laws, regulations and approvals of the ratification to protect the environment from destruction and most of these laws have attempted to have a Crime of destructive activities of the environment, resulting in a concept called environmental offense the fist rules and regulations related to fishing and hunting in civil law. Materials 179 and 189; the Hunting-Law (Act 1957/02/23) and Hunting-fishing law (Act 1967/06/09) was solely about the natural environment; However, the first comprehensive rule that is relative to all aspects of the environment and the restructuring of the organization's of the environment, has also been the protection of the dated 1974/06/18. Rapid and decisive confrontation with environmental crimes can have a deterrent impact on the reduction of violations against the environment what is considered by laws and regulations indicates that the science of law has been determined to preserve the nature, a wide amount of laws have been approved in this regard the main trustee of the environment in Iran must be considered as the environment protection organization the most important goals of this organization are measures such as the realization of article fifty of the constitution of the Islamic Republic of Iran in order to protect the environment and ensure the right and continuous benefit of the country's biodiversity conservation. The policy of the conservation of the environment including the duties of this organization is to prevent and deny pol/ution and any detrimental action that causes both the balance and environmental suitability in addition to government institutions many NGOs strive to protect the environment. Environmental works have been a bit of a good growth but the quality growth of these organizations has not been able to have a high curve growth, which should be investigated. In general, we must say that the situation of the environment in the entire word including our country is not eligible.

So that this common Human capital is being slowed down, therefore, the laws and regulations have been enacted to halt this process. Bat along with these rules and regulations what can solve the problem of environmental degradation, is to institutionalizing environmental ethics in such a way that every person obligate their own to protect the environment. In addition to the passage of preventive and efficient laws and more 
importantly their serious implementation can be effective in protecting the environment better (khaledi, 2001: 23).

In that research we aimed to investigate the role of NGOs in the prevention of environmental crimes.

Today, NGOs are contributing to the criminal justice system in order to achieve their goals on the one hand, with their duties in the field of reporting and report of crimes, the criminal justice system helps in the discovery and pursuit of crimes, and on the other hand they contribute to the criminal process to particular offenders. In addition, with the sensitivity of public opinion and advertising and timely notification, they can play an important role in supporting the environment.

Realization of the environmental goals regardless of the role of NGOs in various stages of the formation of environmental norms and monitoring and implementation is difficult social bang a crime phenomenon requires that even the prevention and suppression of crimes are used by all social capacities the participation of NGOs in the penal process is considered one of these capacities which can be effective in the success of prevention programs in society therefore participatory approach and a option of preventive measures can prevent the occurrences of many environmental crimes.

\section{Existing status of NGOs in light of the preventive approach of environmental crime}

In the definition of such environmental NGOs "non governmental environmental organizations are considered to be nongovernmental nonprofit and non political organizations which are voluntarily and organized by the gathering of real persons in a way that these individuals raw codified with the compilation of the constitution the date of registration in the official authorities of the country and as a legal entity for the realization of common goals and aspirations in the field of protection and protection of the environment to activity at the level of cities and villages of the country and if possible at an international level"(rashidpour, 2003: 5). 
In the constitution of the Islamic Republic of Iran in the field of preservation of the environment and the legitimacy of the establishment and activity of NGOs two important principles have been predicted. In essence fiftieth this environmental ${ }^{1}$ protection Act has been considered a public task. In addition activities that do not provide pollution or destruction and environmental are prohibited by virtue of this principle all iranin people are required to protect and protect their environment Accordingly establishment and participation in nongovernmental environmental organizations and their membership can be constitution and in order to protect the environment and sustainable development ${ }^{2}$.

The second major, based on which the creation and activity of NGOs is inferred, article twenty-sixth of the Constitution is the basis of the principle of freedom of assembly in article 20 of the Universal Declaration of Human Rights, the principle of which "parties, populations, political associations and guilds Islamic associations or religious minorities are formation, provided that they do not violate the principles of independence, freedom, national unity, Islamic standards and the basis of the Islamic Republic. No one can be prevented from participating in them or forcing them to participate in one of them. "Essentially, the goals and aspirations stipulated in the basic rules are of a significant generalization, which is to abstain from entering into detail and relegated it into ordinary laws.

In this regard, the principle addresses two issues related to the formation of nongovernmental organizations: First, the principle of freedom of assembly and the other principle of participation freely in these societies. In fact, the legislator has asked to work with words such as populations and communities to include popular gatherings (NGOs); In the recent part, the principle of the right of individuals, for the company or the lack of participation in any of these gatherings has also been raised.

According to what was said the role of NGOs in participatory prevention is investigated compared to environmental crimes.

\subsection{The embryonic process of participatory prevention in relation to environmental crimes.}

There is no comprehensive and independent law regarding participatory prevention, as crime prevention programs are generally formed in a completely formal and 
governmental platform and have not considered a good position for NGOs (Mansour Abadi, Ebrahimi, 2000: 26). Secondly, the issue of prevention of environmental crime is less attention.

Nowadays, crime prevention programs are not easy in the form of a formal government; the success of these programs depends on the participation of all actors in civil society. In this regard, important international environmental related documents, such as the Rio Declaration and Order 21, include elements that emphasize the participation of all nonstate actors for environmental protection. Chapter Twenty-three of Recognition 21 emphasizes the role of major groups and emphasizes the commitment and commitment of all social groups to the realization of the goals of policies and mechanisms. Chapter Twentyseven is dedicated to strengthening non-governmental organizations the document identifies organizations as partners for sustainable development. The beginning of the chapter begins with the following statement: "NGOs play a vital role in the process of democracy." These organizations are diverse in terms of the geographical scope of activities (local, regional, national and global), and the subject matter (human rights, Humanitarian law, development and environment, etc.).

\subsection{Participatory prevention in the field of the environment}

In terms of function, the nature of non-governmental organizations' actions is more likely to be non-custodial prevention, since the means and methods used by these organizations do not have a police and repressive aspect. The practices are typically nonviolent; in this respect, they cannot be compared to the mechanisms of the violent and reactionary actions of state institutions.

Therefore, environmental NGOs are working to inform, educate, and mobilize public opinion and to raise awareness about the environmental situation by taking preventive measures as follows. 


\subsection{Informing the situation of local, regional, national and international environment}

Information is one of the most commonly used methods of these organizations. In general, public access to information and participation is not restricted to environmental regulations. Rather, this right is related to the citizens before the government, in all democratic systems. Here, the issue of information and citizen participation is important, because with its participation in making decisions, a suitable platform for democracy is provided. On the other hand, the observance of this right to citizens reflects the attention of statesmen to pluralism and the sharing of people's efforts in the administration of the affairs of the country and their right to determine their own destiny.

It should be noted that some nongovernmental organizations active in the field of the environment have accurate information; this information can help decision-makers and criminals in large industrial plans to contribute to environmental issues.

\section{Mobilize public opinion}

One of the powerful tools of these organizations at the national and international level is their outsider demonstration, which transforms them into a powerful push group. The actions of these organizations are diverse; In a way, it is a strong objection from an ecological non-state organization to nuclear testing of a country at sea until a coalition is formed to combat anti-personnel mines and the establishment of an international criminal court. Therefore, these organizations are due to the formal and informal status that they have included in the international arena. They can, in turn, be the source of influence in international relations.

Despite the many efforts of non-governmental organizations in Iran, these organizations have not yet been able to adequately locate their true status and act in a way to mobilize public opinion to protect the environment and prevent environmental crime. 


\section{Education}

Education plays an important role in the prevention of environmental degradation and pollution; therefore, NGOs have begun training on nature networks and how they want to become involved with the formation of environmental networks. The establishment of specialized workshops for educating various people, including women, students and children, has been in this direction. The main purpose of these tutorials is to become more familiar with the environment and to exchange information and experiences.

\section{The right of non-governmental organizations to lodge claims on environmental issues}

Explaining the role of nongovernmental organizations in preventing environmental crime requires that the legal system of Iran be investigated in the identification of the right of appeal to these organizations.

In Iran's law, explicitly, no law does not identify the right of the NGO to the judicial authorities, and limits such a right to state custodians by virtue of the issue (Ramezani Ghavam Abadi, 2008: 102). This legal vacuum creates many practical problems for environmental organizations that seek to respond to environmental damage. Nevertheless, in Iran's law of law, with the exception of some disparate rules and providing a straightforward interpretation of them, the right of access to judicial authorities can be deduced.

\subsection{The Constitution}

Principle thirty-four of the Constitution states: "Litigation is the absolute right of every person, and anyone can refer to competent courts for the purpose of litigation. All people have the right to have such trials available, and nobody can be prohibited from a court that has the right to refer to it under the law. " 
Considering words such as "every person," "everyone," "everyone in the nation," and "no one" in the constitution, imply that there is a legal basis for the presence of nongovernmental organizations in proceedings.

Also, under the fifth principle of the constitution: "In the Islamic Republic, the protection of the environment that the present generation and subsequent generations must have in this social life is considered as a public duty ...." The question is can environmental lawsuits be considered a "public duty"? The positive answer to this question is reinforced by reference to the principles of the eighth and ninth of this law. According to the 8th principle, "In the Islamic Republic of Iran, the invitation to goodness, the proclamation of good and forbidding the denial is the common duty of the public towards each other, the government towards the people and the people towards the state. The conditions and limits and the quality of it are determined by law ... ". According to the 90th principle, "Anyone who has a complaint about the work of the parliament, the executive branch or the judiciary, can submit his complaint in writing to the Islamic Consultative Assembly ..." The term "everyone" mentioned in this article can cover all natural and legal persons. Hence, it would not seem possible that environmental NGOs would be deprived of the right of access to justice for protecting the environment.

\subsection{Implementing Code of Establishment and Activities of NGOs}

As stated above, the right to claim from non-governmental organizations regarding environmental offenses is used by some of the constitutional principles; In addition, among the other rules of the ruling, the Executive Board of the founding and activity of NGOs approved by the Cabinet of Ministers on May 28, 2005, referred directly to this matter. This regulation allows non-governmental organizations to act in accordance with the provisions of this Code and other relevant laws and regulations in accordance with their respective laws and regulations, and to take action in judicial and quasi-judicial jurisdictions. In accordance with Article 16 of this Code, "[NGOs] have the right to lodge a complaint with the judicial authorities in matters of their activities and in support of the general interest against individuals and legal entities." 
This is the only material that allows non-governmental organizations to file a lawsuit in the name of public interest. Hence, the right to litigation is generally accepted for these organizations; they can contest the issue of their activities in support of the public interest. The reference to "public interest" in this article is consistent with the provisions of Article 50 of the Constitution; Because environmental protection in this principle is considered "public duty". Accordingly, environmental NGOs' donations to protect the environment are a "public duty" that is being conducted by these organizations at the trial stage.

Despite what has been said, the prediction of such a right is a matter of reflection because they are in the form of regulations as regulations and not laws; therefore, they lack the guarantee of enforcing the law and, accordingly, according to Article 170, "judges of the courts are required to execute ratifications and Government regulations that oppose Islamic laws or regulations are outside the scope of the executive powers and anyone can request the revocation of such regulations from the Administrative Justice Court "(Tabatabai Mu'tammuni, 2002: 289-287).

In addition, granting the right to participate in all stages of the proceedings and the right to protest the opinions of the judicial authorities is a symbol of the existence of "legal interest" for such organizations as the beneficiary of these claims, the fact that this right under the third chapter of the bill, entitled "Duties And the powers of the prosecutor ", which in turn expresses the granting of a function and pseudo-prosecutorial role to the NGOs, which is an irreplaceable innovation in Iranian law.

\section{Environmental Challenges of Iranian Criminal Law}

With the adoption of new Iranian law to protect the environment, it has taken a step forward, but it still faces problems such as the lack of coherent law and proper criminal response.

\subsection{Non-prediction of a coherent and regular legal collection}

One of the basic principles of criminal policy is to predict a coherent and systematic set of rules in order to meet its goals. The principle of the legality of crime and punishment 
requires that a set of crimes and punishments be presented in a single, coherent set so that a set of criminal law subjects can be readily and transparently and comprehensively acquainted with a set of criminal offenses. Accordingly, as far as possible criminal offenses should be reflected in the general criminal law. This practice has many benefits in practice, because of this action, the collection of legal materials is more coherent and more orderly and the legislator is more careful with the legal material. The existence of numerous laws and increasing criminal offenses causes the confusion of criminal law enforcement agents, so that sometimes judges who enforce laws are regulated by the recognition of an abusive or outdated law set. Usually, a single spirit governs it and the legislator or politician takes specific objectives for it, and thus criminalization and punishment are regulated according to those general goals. (Koushky, 2009: 89).

The legislator in Iran's criminal system has taken a combined approach to this issue. And environmental offenses are reflected in the Islamic Penal Code and in disparate laws.

\subsubsection{The Islamic Penal Code}

As a general matter about environmental pollution, article 688 can be cited: "Any action that may be considered as a threat to public health, such as contaminating drinking water or distributing contaminated drinking water, disposing of non-human waste and animal and animal waste, Spillage of poisonous substances in rivers, street garbage and unauthorized slaughter of animals, unauthorized use of raw sewage or sewage treatment waste water treatment plants for agricultural purposes is prohibited, and perpetrators, if not subject to more severe penalties under the laws, may be imprisoned for up to one year. Will be convicted. Note 1- Determining whether the action is a threat to public health and environmental pollution, as well as the unauthorized destruction of livestock and the disposal of livestock excrements, as well as the declaration of the said offense, as the case may be, by the Ministry of Health and Medical Education, the Environmental Protection Agency and the Organization Will be veterinarian. Note 2. The purpose of environmental pollution is to disperse or mix foreign substances into water or air or soil or earth to a level that has a physical, chemical or biological quality such that it has human or other living 
organisms or plants or works or buildings It is harmful to change. However, the following can be distinguished:

Combat property and natural resources, Article 675 of the Islamic Penal Code

Unauthorized hunting and fishing 679,680 and 688

Destruction of natural resources of Articles 675, 684 and 690 of the Islamic Penal Code

Air Pollution, Article 688 of the Islamic Penal Code

Soil Pollution, Article 688 of the Islamic Penal Code ${ }^{3}$

\subsubsection{Specific rules}

In the various laws and laws that have been scattered and specifically criminalized, it has increased the scope of environmental crime.

Protection of forests in rangelands and trees Materials 42 to 47 of the Law on Protection and Use of Forests and Ranges Amended 1346 Articles 1 and 6 of the bill on conservation and extension of green spaces in cities approved in 1992.

Protection of seas and waters; Article 60 of the Water Act and Nationalization of Water Act 1969; Article 46 of the Fair Water Distribution Law, adopted in 1982; Article 12 and Article 12 of the Hunting and Fishing Act; Article 2 of the Law on

Protection of the Sea and the Borders of the Contamination of Materials Oil approved in 1976; Clause 6 of the Law on the exploitation of water resources of the Islamic Republic of Iran approved in 1995.

Prevention of air pollution; Article 2 of the Law on the prevention of air pollution adopted in 1996; Prohibition of the establishment of harmful buildings and workshops in the cities and suburbs adopted in 1950; Executive Code; Note 6 of the Law on Pollution Prevention and Approval Act; 1990/11/21 Council of Ministers on air.

Protection of Natural Species; Articles 10 to 13 of the Hunting and Fishing Act adopted in 1346; Article 22 of the Law on Protection and Exploitation of Aquatic Resources of the Islamic Republic of Iran, adopted in 1995.

Soil Pollution; Article 9 of the Environmental Protection and Enrichment Law and its Note; Article 11 of the Land Use Rights Act. Illustrated Beach. 1354. 
It can be deduced from all of these materials that although the Iranian legislator has never been able to preserve the environment and wildlife in general and in an interconnected set, but in the case of crime with all the disadvantages of the eye I do not face up. Hence, other forms of crime are punishment.

\subsection{Types of Criminal Responsibilities for Environmental Crimes in Iranian Law}

What is important about environmental crime is that most of these crimes are committed by known individuals in order to achieve higher profits and past calculations. Therefore, if the selective penalties imposed by the legislator are not in the interest of protecting the environment, we will see the lack of appropriate penalties in practice.

Criminal responses to Iranian law have many forms, such as:

Imprisonment

Fine

Imprisonment and criminal cash

Compensation and confiscation of property

The whip

And...

Of course, in Iran's law, most of the reactions have been imprisoned, fined and confiscated.

\subsubsection{Imprisonment}

The term of imprisonment has been set at various times in the criminal code of the environment:

Article 47 of the Law on Protection and Exploitation of the Forests and Rangelands of the Country Anyone who deliberately fires in the forest will be sentenced to a second-degree detention order of three to ten years.

According to article 675 of the Islamic Penal Code, if a person causes a fire in the nature and natural resources and the various property referred to in this article, he will be sentenced to two years' imprisonment. 
According to Article 55 of the Law on Protection and Exploitation of Forests and Rangelands, if one has violated these resources for the purpose of seizing national resources in the country's forests, it will be sentenced to a term of imprisonment of not more than three years.

Under Article 688 of the Islamic Penal Code, if a person threatens public health, such as contaminating drinking water or distributing contaminated drinking water, the other cases referred to in the article will be sentenced to a term of imprisonment of up to one year, provided that There is no more severe punishment under that law.

\subsubsection{Fine}

Cash penalty is one of the most commonly used punishments for environmental crime, either in isolation or in combination with other penalties. The most important defect of cash penalty as a penalty is the impact of a cash penalty on currency fluctuations. The cash penalty covers a wide range of environmental offenses, some of which are cited. The period of this punishment in Iran's rights is from at least five hundred rials to fifty thousand rials in accordance with Article 12 of the Law on Environmental Protection and Enrichment, adopted on $1974 / 05 / 28$ and amendments of $1992 / 10 / 24^{4}$ to 300 thousand rials in accordance with Article 30 of the Air Pollution Prevention Act Due to the devaluation of money in Iran, these penalties cannot have a deterrent effect.

\subsubsection{Imprisonment and criminal cash}

Confiscation and seizure of property is one of the most effective environmental offenses that eliminates the risk of environmental crime, which increases and benefits. For example, Article 22 of the Republic of Iran Law on Protection and Exploitation of Water Resources of the Islamic Republic of Iran is included in paragraph (c). The Iranian Fisheries Company may file a lawsuit against the perpetrators of the offense or the offenses in question. The court deserves to condemn the person, in addition to the fine, to seize the fishing products and the means of fishing, according to the degree and degree of the offense. 


\section{Conclusion}

In environmental trials, the legal provision required by NGOs to "make a statement" of the lawsuit is to provide evidence of the crime of participation in all stages of the investigation of a crime, and finally, "protesting the votes of the courts" is a major development, which, on the one hand, removes one of the Gaps in the legal system of Iran, on the other hand, guarantee the effective participation of these organizations in the implementation of environmental norms; In addition, the realization of the effective participation of such institutions in the criminal process, the expansion of environmental protection cadres leads from government to non-state custodians.

In a general conclusion, the major obstacles faced by these organizations in preventing and suppressing environmental crime are the following factors: some of these factors are related to these organizations, and others are beyond their control:

The excessive diversity of NGOs in the field of the environment and the lack of coordination in determining the goals and mechanisms for implementation between them;

The weak relationship between these organizations and the government and public institutions;

Dissemination of environmental duties and responsibilities between governmental organizations and organizations on the environment;

The lack of a comprehensive and independent legal framework for the establishment and operation of non-governmental organizations;

The lack of effective legal mechanisms for the active participation of these organizations in the criminal process;

The vacuum of the Ministry of the Environment and the lack of accountability of the head of the Environmental Protection Organization in front of the Islamic Consultative Assembly.

Nonetheless, what can be most effective in preventing and suppressing environmental crime is creating an appropriate environment for public participation in environmental protection in the form of nongovernmental organizations; the realization of 
this participation requires open access to environmental information of public participation People are in the process of decision-making, decision-making, justice and environmental justice.

\section{References}

GHASEMI, NASER. (2005). Environmental Criminal Law, Tehran, Jamal-e-Haq.

KHALEDI, SHAHRIAR. (2001). Environmental Basics (General and Iran), Tehran, Shahab Publication.

KOUSHKI, GHOLAM HOSSEIN. (2009). The Challenges of Iran's Criminal Code in the Field of Environmental Crime. "Legal Information Journal, Nos. 17 and 18; 87-104.

MANSOOR ABADI, ABBAS, EBRAHIMI, SHAHRAM. (2002). Transformations in Crime Prevention, Journal of Crime Prevention Studies, Third Year, No. 8.

RAMEZANI GHAVAM ABADI, MOHAMMAD HUSSEIN. (2008). Reflection on the Role and Structure of Non-Governmental Organizations in Environmental Criminal Cases. Useful Legal Letter, Vol. 4, No. 1.

RASHIDPOUR, LOGHMAN. (2003). Review and analysis of the functioning of environmental NGOs in .(2003). the Office of Public Participation of the Environmental Protection Organization.

TABATABAI MO'TAMNI, MANOUCHEHR. (2002). Administrative Law, Tehran, Iran.

1"In the Islamic Republic, protection of the environment that today's generation and subsequent generations must have a growing social life is considered as public duty. Therefore, economic and other activities that can be accompanied by environmental pollution or non-compensated destruction are prohibited.

${ }^{2}$ Since the last two decades, Iran has witnessed considerable quantitative and qualitative development of NGOs. In this meantime, non-governmental environmental organizations have had a considerable growth, in the same manner that there are about five hundred NGOs in this field that are active in regional and local national levels. One of the important and decisive factors in the increase of the number of these organizations should be considered in the growth and development of people in society and respect for the fundamental rights of people in the form of societies and assemblies and participation in them. According to the latest statistics presented by the environmental organization in June 1385, a total of 400 and ninety two environmental NGOs are active. Active organizations in Tehran and other provinces, names, name, address and 
status of registration and reference of their registration are collected by the organization and can be accessed on the organization's website.

${ }^{3}$ Article 675 - Anyone intentionally firing a building or a building or a ship or an airplane or a factory or a building in general in any residential or residential area for the purpose of settling with the forest or the land, or any type of crop or land or fields or gardens belonging to another. Sentenced to two to five years.

Article 679 - Everyone deliberately and without the necessity of slaughtering the meat of another animal or the animals declared by the state forbidden by hunting them, or killing or poisoning, or wasting or defective, shall be imprisoned from ninety one days to six months with a fine of One million five hundred rials to one million rials will be condemned.

Article 680. Everyone, contrary to the regulations and without legal authorization, hunting or fishing protected wild animals and wild animals shall be sentenced to three to three years' imprisonment or a fine of one and a half million rials to eighteen million rials.

Article 684- Anyone who produces another product, or thaksat, or fruit garden, or palm grown, destroys or harms another person, or harvested or harvested another product, or is liable to be damaged by the theft or destruction of water belonging to such property, or by other measures of other means It can be used or used for another purpose, it is sentenced to six months to three years and lasts for up to 74 strokes.

Article 686 - Any tree in the subject matter of the article provides for the destruction of green space and, in contravention of the said law, discontinues or causes them to be destroyed, in addition to the compensation for incurring, in accordance with the case, the imprisonment period from six months to three years or a cash penalty From three million to eighteen million rials.

Article 690- Everyone by plotting to produce the effects of seizure on arable land, whether cultivated or cultivated in forests and nationalized rangelands, mountains, gardens, settlements, water resources, springs, natural sanctuaries and national parks, Agricultural and animal husbandry, animal husbandry, agro-industry, land, etc. (lands and real estate belonging to the state or affiliated companies of the state or municipalities or permanent establishments, etc.) or without the permission of the Environmental Protection Agency Other competent authorities shall engage in activities that cause damage to the environment and natural resources, or to engage in any act of rape or harassment, or Mutually rights in these cases the punishment is imprisonment of one month to one year.

Note 1 - The above-mentioned offenses are considered out of place, and the judicial authority, by setting the facial assembly, orders to stop the rape operation until a final verdict is issued.

${ }^{4}$ Those who violate the rules and regulations set forth in the provisions of Article 10, will be fined for a fine of five hundred rials to fifty thousand rials in accordance with the provisions specified in the relevant regulations. 